\title{
A PTEROSAUR MANUS TRACK FROM DENALI NATIONAL PARK, ALASKA RANGE, ALASKA, UNITED STATES
}

\author{
ANTHONY R. FIORILLO, ${ }^{*}$ STEPHEN T. HASIOTIS, ${ }^{2}$ YOSHITSUGU KOBAYASHI, ${ }^{3}$ and CARLA SUSANNE TOMSICH ${ }^{4}$ \\ ${ }^{1}$ Museum of Nature and Science, P.O. Box 151469, Dallas, Texas 75315, USA; ${ }^{2}$ University of Kansas, Department of Geology, 1475 Jayhawk Blvd., 120 Lindley Hall, \\ Lawrence, Kansas, 66045-7613, USA; ${ }^{3}$ Hokkaido University Museum, Kita 10, Nishi 8, Kita-Ku, Sapporo, Hokkaido 060-0810, Japan; ${ }^{4}$ Department of Geology and \\ Geophysics, University of Alaska, Fairbanks, Alaska 99775, USA \\ e-mail: tfiorillo@natureandscience.org
}

\begin{abstract}
We report on the first record of a pterosaur from Alaska. This record consists of a single manus track from the lower part of the Upper Cretaceous Cantwell Formation in Denali National Park, Alaska, United States, making this the northernmost occurrence for this group of reptiles. The specimen is from deposits that record a low-lying floodplain with small lakes and ponds, dissected by small channels that fed a larger tributary stream on an active fan lobe. The dominant vegetation was comprised of conifers with an understory of ferns and horsetails.
\end{abstract}

\section{INTRODUCTION}

Modern high-latitude continental ecosystems have been studied extensively as a means of understanding the interconnectedness of biological, physical, and human components within the Arctic and the implications for biodiversity and climate change studies. Alaska holds additional importance because it is at the geographic crossroad for connecting two major landmasses-Eurasia and North America. This connection between the two continents, referred to as Beringia or the Bering Land Bridge, is the mechanism for faunal exchange extending back to the early Late Cretaceous (Russell, 1993; Sereno, 2000; Fiorillo, 2008a).

Significant effort has been spent examining the vertebrate fossil record of far northern Alaska (Brouwers et al., 1987; Parrish et al., 1987; Nelms, 1989; Clemens and Nelms, 1993; Clemens, 1994; Gangloff, 1998; Fiorillo and Gangloff, 2000, 2001; Fiorillo, 2004, 2006, 2008b; Fiorillo et al., 2005; Gangloff et al., 2005). The Upper Cretaceous rocks of this region contain the densest concentrations of fossil vertebrates of any high latitude location in the northern or southern hemisphere (Rich et al., 2002). As a result of a National Park Service-initiated paleontological survey of the Lower Cantwell Formation (Late Cretaceous) in Denali National Park (DENA), Alaska, Cretaceous fossil vertebrates are now known from the central Alaska Range (Fiorillo et al., 2007). Discoveries of Late Cretaceous dinosaur remains elsewhere in Alaska have demonstrated the widespread nature of a rich continental polar ecosystem (Gangloff, 1995; Fiorillo and Parrish, 2004; Fiorillo et al., 2007).

Here we describe a manus impression attributed to a pterosaur that was discovered in the Lower Cantwell Formation of DENA, central Alaska, in 2008 (Fig. 1). This is the first such occurrence of this group of animals from the far northwestern region of North America, and, by virtue of this occurrence, it provides new insights into the emerging picture of the ancient, high-latitude continental ecosystem in this area during the Late Cretaceous. This report helps fill a geographic gap for this group of ancient flying reptiles, as no other reports exist for this region of North America. It also extends the known northern latitudinal distribution of these animals and contributes to the known

* Corresponding author.

Copyright $\odot$ 2009, SEPM (Society for Sedimentary Geology) biodiversity of ancient Beringia by documenting the occurrence of a fossil vertebrate that had an airborne lifestyle. A pterodactyloid from the Late Cretaceous of New Zealand has previously been reported from a single scapula (Molnar and Wiffen, 1994), so these two records provide a latitudinal range of over $120^{\circ}$ for this group. The recognition of the occurrence of these animals at this northern high latitude illustrates the complexity of the food web in the ancient polar to subpolar continental ecosystem.

\section{GEOLOGICAL SETTING}

The Cantwell Formation is exposed throughout much of the central Alaska Range. This rock unit is thousands of meters thick and comprised of a lower, dominantly fluvial sedimentary unit and an upper, dominantly volcanic unit, referred to as the Lower and the Upper Cantwell Formation, respectively (Ridgway et al., 1997). Gilbert et al. (1976) named the upper unit the Teklanika Formation, but subsequent workers have not accepted this designation. In the most recent study of the stratigraphy of the Cantwell Formation, Ridgway et al. (1997) refer to the unit as the Lower and the Upper Cantwell Formation, and we follow this nomenclature. Deposition of the formation occurred within a basin formed between Wrangellia and the margin of North America during the accretion of the former (Ridgway et al., 1997).

Rocks of the Lower Cantwell Formation are comprised of conglomerates, organic-rich and fossiliferous sandstones, mudstones, and coals. The fluvial setting has been interpreted as an alluvial fan system on the basis of frequent changes in facies and current directions, and evidence for debris flows and syndepositional deformation (Ridgway et al., 1997). A 40-m section was measured and described at the pterosaur fossil track locality in DENA.

Pollen analysis for the Lower Cantwell shows that these sedimentary rocks were deposited during the late Campanian or early Maastrichtian (Ridgway et al., 1997). Given that the southern margin of Alaska was near its current latitude during the Cretaceous (Hillhouse and Coe, 1994), the basin in which the Cantwell was deposited was near its present latitude at the time of deposition.

\section{Facies Descriptions}

The outcrop at the pterosaur track site consists of a 40-m-thick, nearvertical section (Fig. 2). The base of this section is not exposed, and the top is covered by alpine tundra. The lithology consists of conglomeratic and pebbly sandstone, cross-stratified and massive sandstone, interbedded sandstone and siltstone, organic-rich siltstone, and shale, as well as a 4-cm-thick, undulated bentonite layer. Rocks are well indurated; the finer fraction is organic rich, often fossiliferous and sometimes ferruginous. Coarser-grained units are laterally discontinuous and are contained within fine-grained floodplain deposits. The measured section (Fig. 2) shows frequent fining- and coarsening-upward cycles, 


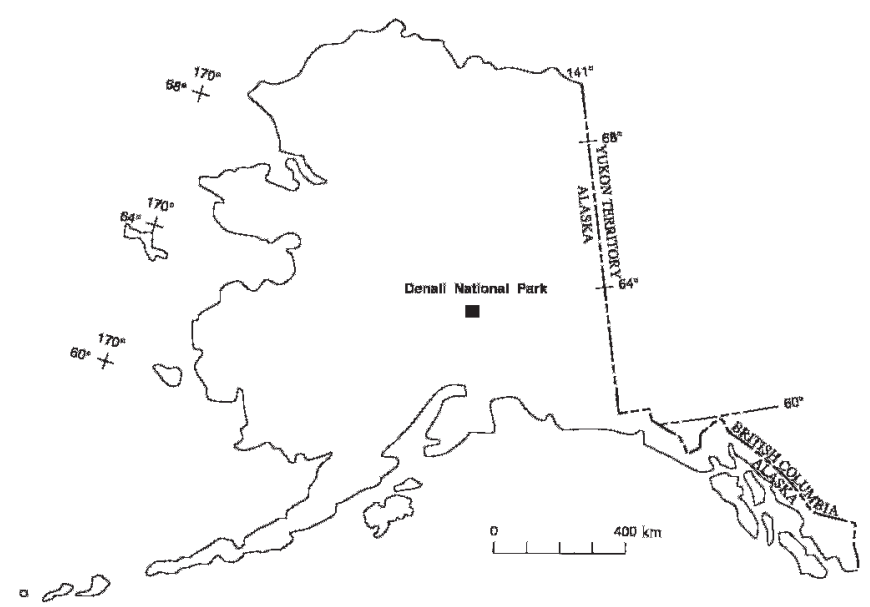

FIGURE 1-Location of Denali National Park, Alaska, United States, shown by black square.

as well as abrupt changes in grain size. Most layers are tabular and consist of massive or thinly interbedded, fine- to very fine-grained sandstones. Sedimentary structures consist primarily of ripples and cross beds. Boundaries between beds are typically abrupt with some local scour surfaces displaying irregular relief. Many beds contain a moderate abundance of rhizoliths, small pieces of permineralized wood, and plant macrofossils. The latter include impressions of fern fronds, Equisetum stems, and rhizomes in growth position, and the trunk, branches, and leaves of Metasequoia and other taxodiaceous conifers. Horizontal surface trails of Mermia and U-shaped burrows of Arenicolites are present, as well as a variety of horizontal and vertical burrows. Iron nodules and a few larger concretions $(<12 \mathrm{~cm}$ long) are also found in these units.

Laterally discontinuous, low-angle, cross-stratified or trough crossstratified, medium-grained sandstones no more than $50 \mathrm{~cm}$ thick are often capped by or grade into black, organic-rich mudstone. Generally, the interbedded units are more fossiliferous and contain abundant rhizoliths and burrows compared to the massive tabular sandstones. Siltstones contain small iron nodules, Metasequoia leaves, and fine rhizoliths. Shales are very friable and highly recessive. The bentonite layer is bounded by thin layers of coaly shale.

Two coarser-grained units occur in midsection and at the top (Fig. 2, $19.65 \mathrm{~m}$ and $35.7 \mathrm{~m}$ ). The 1.25 -m-thick, coarse-grained deposit in midsection is cross-stratified with single layers of pebbles up to $0.5 \mathrm{~cm}$ in diameter on foresets. It is capped by a thin layer of mudstone disrupted by desiccation cracks and horizontal burrows. A $4.30-\mathrm{m}-$ thick, interbedded conglomerate and very coarse pebbly sandstone unit at the top of the section contains pebbles $\leq 6 \mathrm{~cm}$ in diameter. This deposit also contains lenses of medium- to coarse-grained sandstone and thin ( $\leq 15 \mathrm{~cm}$ thick) layers of fine-grained sandstone. It is $\sim 55 \mathrm{~m}$ wide and has an erosive base (Fig. 2). The texture is moderately well sorted and matrix supported; interstratified clasts are subangular to well rounded and rest on low-angle foresets $\left(<15^{\circ}\right)$. A 1.50-m-long log imprint is oriented perpendicular to paleocurrent direction measured from foresets.

\section{Facies Interpretation}

The heterolithic deposits and many fining-upward successions of this section represent the waxing and waning of energies of fluvial channels and floodplain sedimentation on distal alluvial fans, as suggested by Ridgway et al. (1997) for this part of the Cantwell Formation. The interbedded conglomerate and coarse-grained pebbly sandstones represent a larger, multistory channel fill (Miall, 2006); the moderate sorting and range of clast shapes suggest rapid deposition of partially reworked sediment. Smaller bodies of medium- and finer-grained sandstones represent smaller stream fills. Burrowed mud drapes capping the coarser sandstones and desiccation cracks indicate rapid abandonment (Miall, 2006).

The presence of shallow channel fills and tabular sandstones abruptly succeeding fine-grained floodplain deposits suggests a recurrent pattern of avulsion (Jones and Hajek, 2007) that indicates water flow was unconfined. The fine-grained sandstones and mudstones comprise alluvial and lacustrine deposits. Fine- to very fine-grained rippled sandstones grading laterally into siltstones formed along lake margins or overbank deposits. The bentonite and thin, coaly shales likely accumulated within a lake. Fine- and very fine-grained sandstones that are thinly interbedded and rippled with abundant rhizoliths and burrows represent crevasse splays on floodplains; the more heavily burrowed and rooted, very fine-grained sandstones developed further away from active streams. The thinly interbedded sandstone-siltstone couplets represent crevasse splay, channel margin, or overbank deposits. Laterally continuous tabular sandstones may constitute sheetflood deposits (Blair and McPherson, 1994).

The presence of fern fronds and Equisetum stems and rhizome segments in growth position in cross-bedded and massive sandstones suggests that the floodplain was recolonized soon after deposition. Trace fossils represent deposit feeders moving through nutrient-rich sediment. The well-defined pterosaur track and well-defined hadrosaur and bird tracks indicate that the upper part of the sediment was better drained at times. Paleosols, however, are weakly developed and poorly drained due to rapid aggradation.

Overall, the depositional environment is interpreted as a low-lying floodplain containing small lakes and ponds, dissected by small channels fed by a larger tributary stream on an active fan lobe. The dominant vegetation was comprised of conifers with an understory of ferns and horsetails. Trees and other angiosperm shrubs probably lined stream and lake margins. The many lithofacies successions and the different floral compositions testify to the changes occurring in an evolving ancient floodplain. The occurrence of a pterosaur track in this setting suggests that at least northern high-latitude pterosaurs lived out part of their annual cycle in this type of environment.

\section{FOSSIL MATERIAL}

A natural cast of a single manus track (Figs. 3-4, DENA 13313) was recovered as a float block from the Lower Cantwell Formation. The locality was high on a mountain slope and the only rock unit comprising the mountain was Lower Cantwell Formation. Precise locality data are on file with the authors and the Resource Office of DENA. The specimen described here is housed at the Museum of Nature and Science, Dallas, Texas, United States.

The track is asymmetric with three digits, $\sim 18 \mathrm{~cm}$ long, and $\sim 6 \mathrm{~cm}$ at its widest point, not including the digits. The tips of the first and second digit are missing; these two digits are oriented anterolaterally and are shortest. The third digit is the longest and is oriented posteriorly. This track morphologically compares favorably with other tracks attributed to pterosaurs elsewhere in Jurassic-Cretaceous deposits, particularly those illustrated from the Crayssac site (lower Tithonian, southwestern France; Mazin et al., 2003, fig. 3a), the El Pellillal tracksite in the Cerro del Pueblo Formation (latest Campanian, Coahuila, Mexico; Rodriguez-De La Rosa, 2003), and the North Horn Formation (Late Cretaceous, Utah; Lockley, 1999), as well as those from Jurassic rocks in Wyoming and Utah (Lockley et al., 1995). Other large tracks have been described from Gansu Province, China (Zhang et al., 2006), but the illustrations preclude reliable measurements. The track from Denali, however, is most similar in size to the largest track $(\sim 10 \mathrm{~cm}$ long) illustrated from the Cerro del Pueblo Formation (Rodriguez-De La Rosa, 2003, fig. 3a) and is significantly larger than 


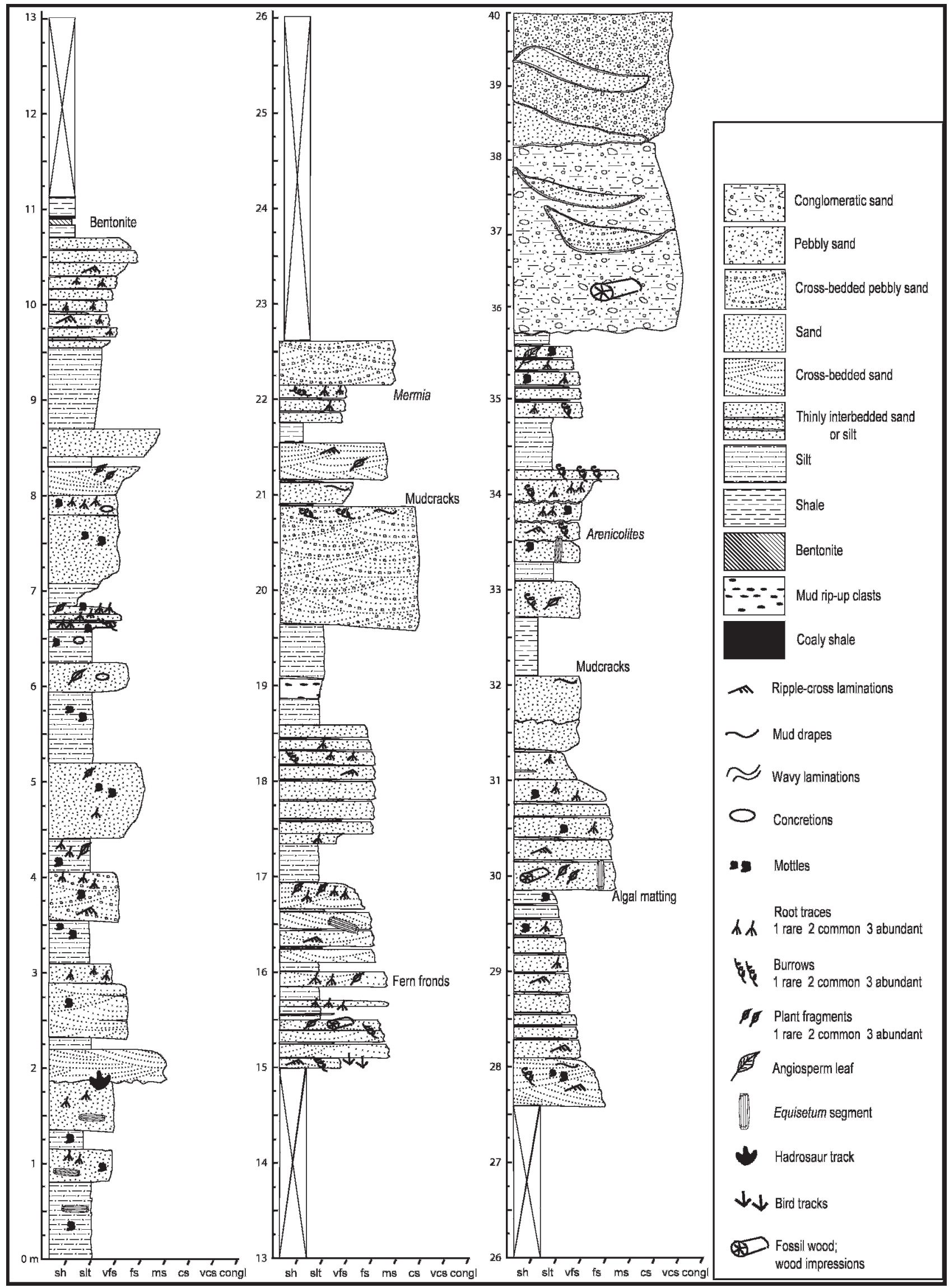

FIGURE 2-Measured section at pterosaur site in the Lower Cantwell Formation. Casts of bird and hadrosaur footprints are preserved at grain-size boundaries at bottom of sandstone beds. 
A

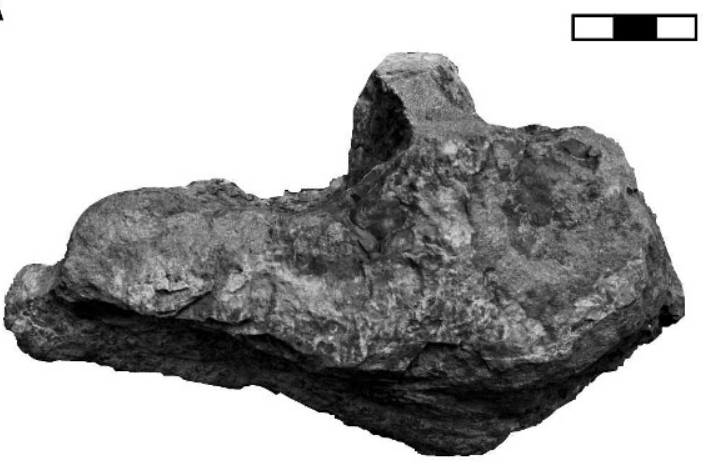

B

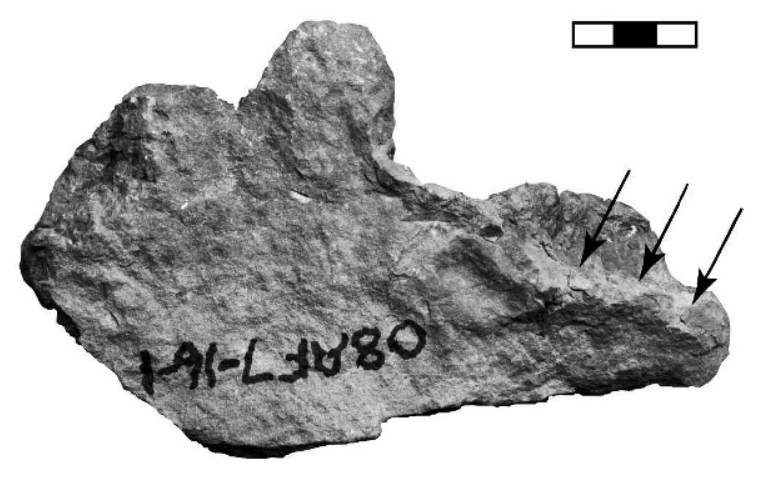

C

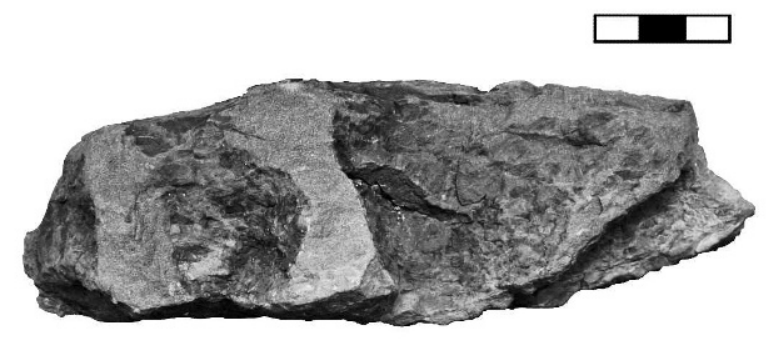

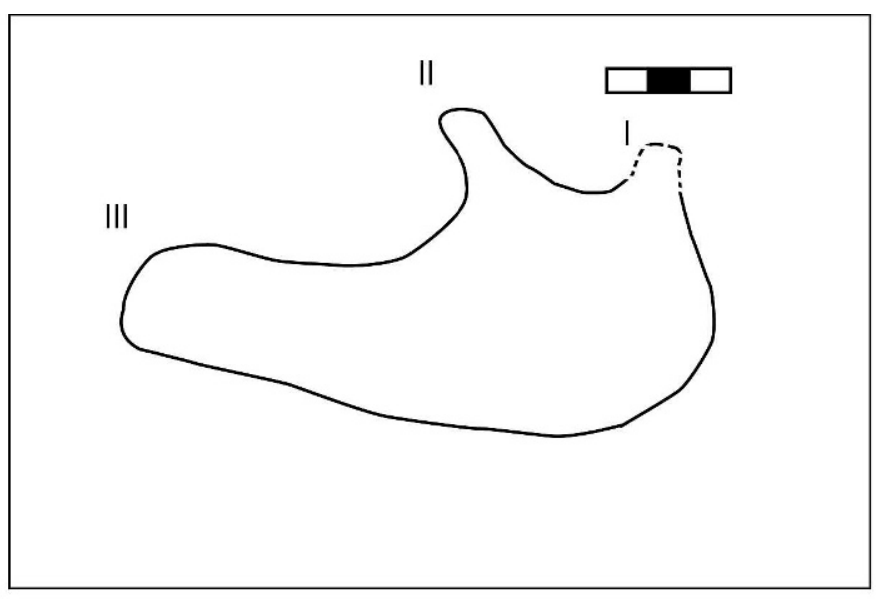
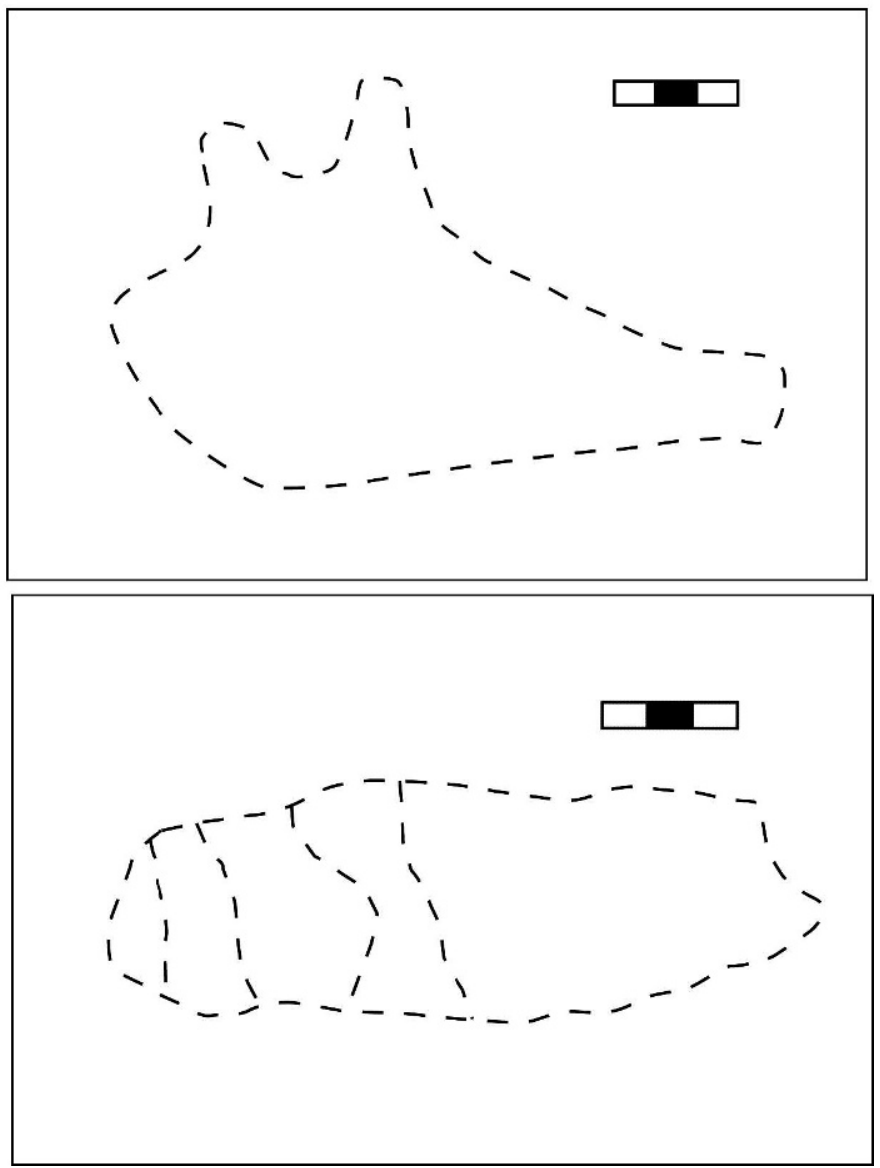

FIGURE 3-Pterosaur manus track (DENA 13313), Pteraichnus isp., shown in A) ventral, B) dorsal, and C) lateral views, from Lower Cantwell Formation of Denali National Park. Digits I, II, and III are noted in A. Arrows in B highlight margin of third digit of track.

the manus tracks from the Crayssac site, which are $\sim 4-6 \mathrm{~cm}$ long (Mazin et al., 2003, fig. 3), and the North Horn Formation, which are $\sim 5-8 \mathrm{~cm}$ long (Lockley, 1999, fig. 2).

\section{DISCUSSION}

Animals that do not have modern analogs, such as pterosaurs, present difficulties in understanding their paleobiology (Buffetaut and Mazin, 2003). Basic biological functions, such as locomotion, can cause lengthy debate among paleontologists. The debate on the validity of pterosaur manus tracks seems to have reached a consensus that such tracks do exist (e.g., Lockley et al., 1995; Mazin et al., 2003), and the specimen described in this report supports that consensus.
It may at first seem problematic that we report on only a manus track rather than both manus and pes tracks. Mazin et al. (2003) have addressed the problem of manus-only pterosaur tracks by pointing out two important variables that are unique to this group. First, the center of mass in pterosaurs is anteriorly displaced, so that they put more body weight on their front claws (hands) than their back ones (feet). Secondly, the print surface area of the hands is smaller than the print surface area of the feet and the additional weight over a smaller area would yield deeper manus tracks. This difference in track depth has been noted in pterosaur tracks from Lower Cretaceous rocks in Gansu Province, China (Zhang et al., 2006). Thus, if only a single track is found, there is a higher probability that it will be a manus rather than a pes track. It seems likely that more pterosaur tracks, 

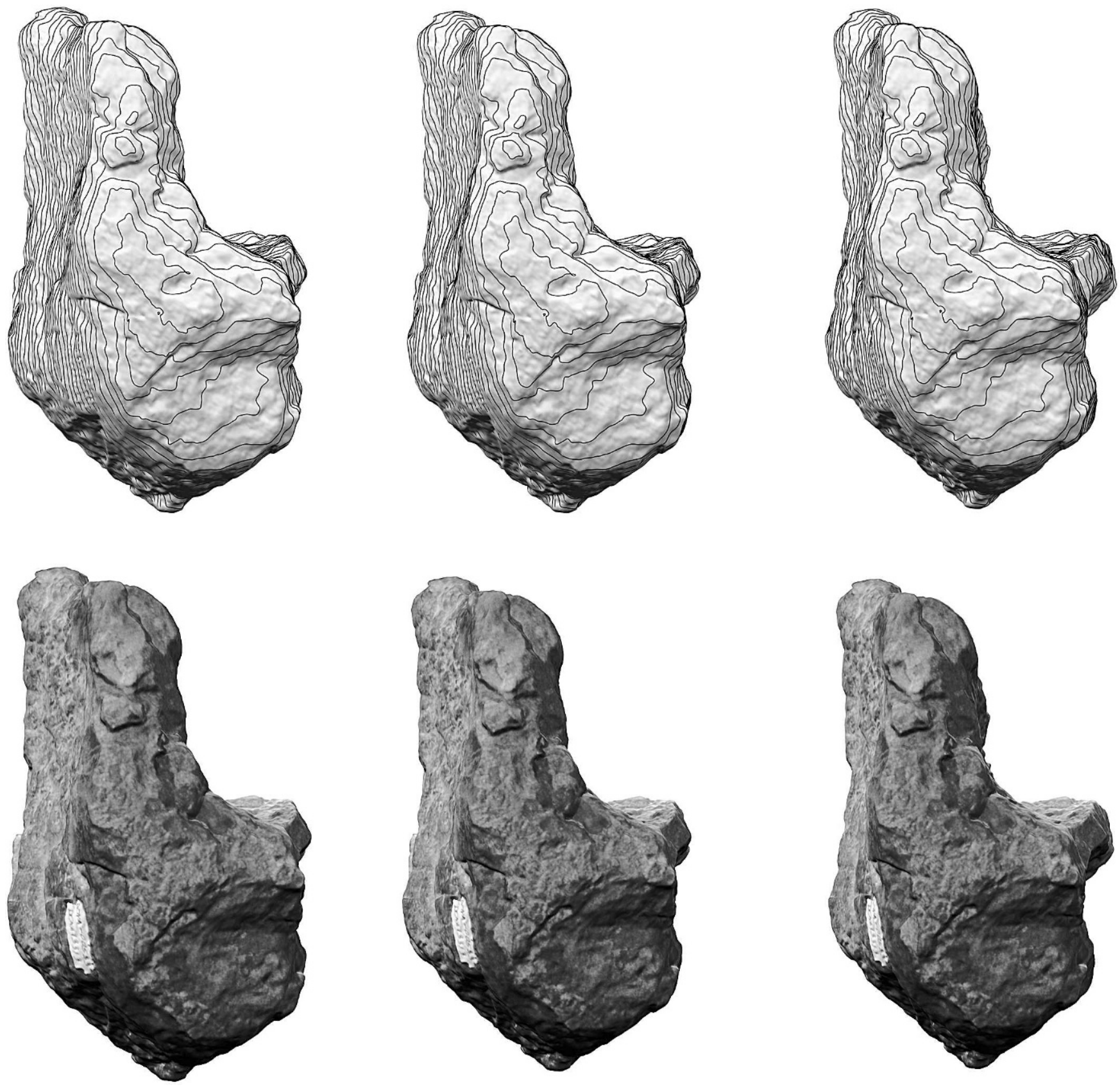

FIGURE 4-Pterosaur manus track (DENA 13313), Pteraichnus isp., shown as scanned and contoured images and in stereo pairs.

both manus and pes, will be discovered in the Lower Cantwell Formation of DENA. Tracks attributed to other members of the family Pteraichnidae, but morphologically distinct from the DENA track, have been noted in the Late Cretaceous of Korea (Hwang et al., 2002).

Frey et al. (2003) identified two types of handprints: a large-clawed form and a short-clawed form. They attribute the former to azhdarchidtype or Pterodactylus-type pterosaurs. The manus track described here compares more favorably with the short-clawed form, indicative of more primitive forms of pterosaurs. This track type is also recorded from the spectacular Jurassic Crayssac site (Pteraichnus isp.; Mazin et al., 1995, 2003). It is tempting to invoke a significant range extension of primitive pterosaurs into the latest Cretaceous based on this Cantwell track, but we urge caution against such a conclusion, given that there is only a single manus track at this time.
Feeding strategies for pterosaurs remains a lively area of discussion. For example, Lockley and Wright (2003) suggested pterosaurs fed on invertebrates, while Lawson (1975) suggested that Quetzacoatlus was a scavenger of dinosaur carcasses. Chatterjee and Templin (2004) proposed a diet that may have included bivalves, snails, crabs, and other invertebrates; large pterodactyloids may have been fish eaters. Wellnhofer (1991) argued that pterosaurs fed on aquatic organisms, ranging from larval and adult crustaceans to fishes, based on the relationship of skeletal remains in coastal deposits. Bakker (1986) suggested that pterosaurs were probing the sediment for invertebrates, but Wellnhofer (1991) pointed out that the walking abilities of pterosaurs likely were not able to support such a feeding strategy. An additional feeding strategy, based on interpretations of the agility of pterosaurs, is that they were insectivorous. Despite the abundance of invertebrate traces in the Lower Cantwell Formation, we concur with 
TABLE 1-Ichnotaxa observed within the Lower Cantwell Formation.

\section{Invertebrates}

Nematodes (Animalia: Nematoda): thin diameter Cochlichnus

Aquatic oligochaetes (Annelida: Oligochaeta): larger diameter Cochlichnus

Mud-loving beetles (Coleoptera: Heteroceridae): Steinichnus

Predaceous diving beetles (Coleoptera: Hydrophilidae): cf. Haplotichnus

Midge fly larvae (Diptera: Chironomidae): cf. Arenicolites; cf. Trichichnus; hopping insects as grasshoppers, katydids, or crickets (Orthoptera: Gryllidae, Acrididae,

Tettigoniidae): hopping traces

Scarab beetles (Coleoptera: Scarabaeidae): Naktodemasis bowni

Soil bugs (Hemiptera: Cydnidae): variable diameter Naktodemasis bowni

Tiger beetles (Coleoptera: Cicindelidae) and Rove beetles (Coleoptera:

Staphylinidae): Cylindricum

Mayflies (Insecta: Ephemeroptera): cf. Arenicolites

No modern analog (cf. Copeza, cf. Lithographus, cf. Bifurculapes, cf. Acanthichnus)

\section{Vertebrates}

Fish traces (Undichna isp.)

Theropoda

Aves

Ornithopoda

Wellnhofer's (1991) interpretation of the walking abilities of pterosaurs and rule out probing as the main means of pterosaur feeding. The most reasonable food choice for pterosaurs in northern high latitudes was fish, a food type also invoked for Ornithocheirus, the dominant southern, high-latitude pterosaur (Wellnhofer, 1991). Such an interpretation is also suggested for the Lower Cantwell Formation pterosaurs based on the common occurrence of fish trace fossils attributable to Undichna. The large size of the DENA pterosaur suggests fishes to be a more likely food choice than the smaller invertebrates.

The physiology of pterosaurs is an additional attribute of the paleobiology of these animals that is under discussion (Unwin, 2006). Endothermy has been suggested in some dinosaurs (including birds), and the presence of dinosaur remains in Alaska is congruent with this idea. On the other hand, the distribution of fossil crocodiles in the Late Cretaceous shows no record in high-paleolatitude environments (Markwick, 1998), implying that Cretaceous crocodiles, like modern crocodiles, were ectothermic and not tolerant of cold climate. The Archosauria includes the Crocodylia, Pterosauria, and Dinosauria, suggesting at least two physiological strategies within this major taxonomic group, with some suggestion that pterosaurs were endothermic (Lu et al., 2005). In a recent study, Seymour et al. (2004) suggested that modern crocodiles are secondarily ectothermic and that ancestral forms were endothermic. Such an interpretation then makes endothermy a character for the Archosauria. The presence of pterosaurs from high-paleolatitude settings (Alaska and New Zealand) is consistent with the implication of Seymour et al. (2004) that pterosaurs, as members of the Archosauria, were endothermic. Recently the skeletons of large pterosaurs have been shown to have increased appendicular pneumaticity and this may have aided in thermoregulation (Claessens et al., 2009). The large size of the DENA pterosaur, as a function of thermoregulation capabilities, is expected given the presumed strong seasonality of this ancient northern environment (Brouwers et al., 1987; Parrish et al., 1987; Fiorillo and Gangloff, 2000, 2001; Fiorillo, 2004, 2008a, 2008b).

\section{CONCLUSIONS}

This is the first documented record of a pterosaur from farthest northwestern North America. The record consists of a single manus track from the Lower Cantwell Formation (Late Cretaceous) of DENA in the central part of the Alaska Range, Alaska, and is from rocks deposited on a low-lying floodplain vegetated dominantly by conifers, ferns, and horsetails. This is the northernmost record for this group of animals.

\section{ACKNOWLEDGMENTS}

We thank the National Park Service, Alaska System Support Office, and Denali National Park for their logistical and financial support for this project, particularly Russell Kucinski, Linda Stromquist, and Phil Brease. We thank Drs. Kenneth Ridgway and Jeff Trop for sharing their experiences with the Cantwell Formation. We also thank Martin Lockley and Richard McCrea for their thoughtful reviews of this paper. Mike Polcyn and Thomas Adams, Southern Methodist University, provided the images in Figure 4. We gratefully acknowledge the support of the Museum of Nature and Science, American Airlines, and Whole Earth Provision Company for support in the field.

\section{REFERENCES}

Bakker, R.T., 1986, The Dinosaur Heresies: W. Morrow and Co., Inc., New York, $481 \mathrm{p}$.

Blair T.C., and McPherson, J. G., 1994, Alluvial fans and their natural distinction from rivers based on morphology, hydraulic processes, sedimentary processes, and facies assemblages: Journal of Sedimentary Research, v. 64A, p. 450-489.

Brouwers, E.M., Clemens, W.A., Spicer, R.A., Ager, T.A., Carter, L.D., and Sliter, W.V., 1987, Dinosaurs on the North Slope, Alaska: High latitude, latest Cretaceous environments: Science, v. 237, p. 1608-1610.

Buffetaut, E., and Mazin, J.-M., 2003, Evolution and palaeobiology of pterosaurs, in Buffetaut, E., and Mazin, J.-M., eds., Evolution and Palaeobiology of Pterosaurs: Special Publications 217, Geological Society, London, p. 1-3.

Chatterjee, S., and Templin, R.J., 2004, Posture, locomotion, and paleoecology of pterosaurs: Geological Society of America Special Paper, v. 376, p. 1-64.

Claessens, L.P.A.M., O'Connor, P.M., and Unwin, D.M., 2009, Respiratory evolution facilitated the origin of pterosaur flight and aerial gigantism: PLoS ONE, v. 4, e4497, 8 p., doi:10.1371/journal.pone.0004497.

Clemens, W.A., 1994, Continental vertebrates from the Late Cretaceous of the North Slope, Alaska, in Thurston, D.K., and Fujita, K., eds., 1992 Proceedings, International Conference on Arctic Margins (Anchorage, Alaska, 1992): U.S. Minerals Management Service, Alaska Outer Continental Shelf Region, v. MMS94-0040, p. 395-398.

Clemens, W.A., and Nelms, L.G., 1993, Paleoecological implications of Alaskan terrestrial vertebrate fauna in latest Cretaceous time at high paleolatitudes: Geology, v. 21, p. 503-506.

Fiorillo, A.R., 2004, The dinosaurs of arctic Alaska. Scientific American, v. 291, no. 6, p. $84-91$

Fiorillo, A.R., 2006, Review of the dinosaur record of Alaska with comments regarding Korean dinosaurs as comparable high-latitude fossil faunas: Journal of Paleontological Society of Korea, v. 22, p. 15-27.

Fiorillo, A.R., 2008a, Cretaceous dinosaurs of Alaska: Implications for the origins of Beringia, in Blodgett, R.B., and Stanley, G., eds., The Terrane Puzzle: New Perspectives on Paleontology and Stratigraphy from the North American Cordillera: Geological Society of America Special Paper, v. 442, p. 313-326.

FIorillo, A.R., 2008b, On the occurrence of exceptionally large teeth of Troodon (Dinosauria: Saurischia) from the Late Cretaceous of northern Alaska: PALAIOS, v. 23 , p. $322-328$.

Fiorillo, A.R., and Gangloff, R.A., 2000, Theropod teeth from the Prince Creek Formation (Cretaceous) of northern Alaska, with speculations on arctic dinosaur paleoecology: Journal of Vertebrate Paleontology, v. 20, p. 675-682.

Fiorillo, A.R., and Gangloff, R.A., 2001, The caribou migration model for Arctic hadrosaurs (Ornithischia: Dinosauria): A reassessment: Historical Biology, v. 15, p. $323-334$.

Fiorillo, A.R., and Parrish, J.T., 2004, The first record of a Cretaceous dinosaur from western Alaska: Cretaceous Research, v. 25, p. 453-458.

Fiorillo, A.R., McCarthy, P.J., Breithaupt, B., and Brease, P., 2007. Dinosauria and fossil Aves footprints from the Lower Cantwell Formation (latest Cretaceous), Denali Park and Preserve, Alaska: Alaska Park Science, v. 6, p. 41-43.

Fiorillo, A.R., Triplehorn, D., Layer, P., and Ferguson, K., 2005, First evidence of Cenomanian dinosaurs in Alaska: Further insight into the Cretaceous origin of Beringia: Journal of Vertebrate Paleontology, v. 25, no. 3, supplement, p. 57A.

Frey, E., Tischlinger, H., Buchy, M.-C., and Martill, D.M., 2003, New specimens of Pterosauria (Reptilia) with soft parts with implications for pterosaurian anatomy and locomotion, in Buffetaut, E., and Mazin, J.-M., eds., Evolution and Palaeobiology of Pterosaurs: Special Publications 217, Geological Society, London, p. 233-266. 
Gangloff, R.A., 1995, Edmontonia sp., the first record of an ankylosaur from Alaska: Journal of Vertebrate Paleontology, v. 15, p. 195-200.

Gangloff, R.A., 1998, Arctic dinosaurs with emphasis on the Cretaceous record of Alaska and the Eurasian-North American connection, in Lucas, S.G., Kirkland, J.I., and Estep, J.W., eds., Lower and Middle Cretaceous Terrestrial Ecosystems: New Mexico Museum of Natural History and Science Bulletin, v. 14, p. 211-220.

Gangloff, R.A., Fiorillo, A.R., and Norton, D.W., 2005, The first Pachycephalosaurine (Dinosauria) from the Paleo-Arctic and its paleogeographic implications: Journal of Paleontology, v. 79, p. 997-1001.

Gilbert, W.G., Ferrell, V.M., and Turner, D.L. 1976. The Teklanika FormationA new Paleocene volcanic formation in the central Alaska Range: Alaska Division of Geological and Geophysical Surveys Report, v. 47, p. 1-16

Hillhouse, J.W., and Coe, R.S. 1994. Paleomagnetic data from Alaska, in Plafker, G., and Berg, H.C., eds., Geology of Alaska: The Geology of North America, v. G-1, Geological Society of America, Boulder, Colorado, p. 797-812.

Hwang, K.-G., Huh, M., Lockley, M.G., Unwin, D.M., and Wright, J.L., 2002, New pterosaur tracks (Pteraichnidae) from the Late Cretaceous Uhangr Formation, southwestern Korea: Geological Magazine, v. 139, p. 421-435.

JoNES, H.L., and HAJEK, E.A., 2007. Characterizing avulsion stratigraphy in ancient alluvial deposits: Sedimentary Geology, v. 202, p. 124-37.

Lawson, D.A., 1975, Pterosaur from the latest Cretaceous of West Texas: Discovery of the largest flying creature: Science, v. 187, p. 947-948.

Lockley, M.G., 1999, Pterosaur and bird tracks from a new Late Cretaceous locality in Utah, in Gillette, D.D., ed., Vertebrate Paleontology in Utah: Utah Geological Survey, Miscellaneous Publication, v. 99-1, p. 355-360.

Lockley, M.G., Logue, T.J., Moratalla, J.J., Hunt, A.P., Schultz, R.J., and Robinson, J.W., 1995, The fossil trackway Pteraichnus is pterosaurian, not crocodilian: Implications for the global distribution of pterosaur tracks: Ichnos, v. 4, p. 7-20.

Lockley, M.G., and Wright, J.L., 2003, Pterosaur swim tracks and other ichnological evidence of behaviour and ecology, in Buffetaut, E., and Mazin, J.-M., eds., Evolution and Palaeobiology of Pterosaurs: Special Publications 217, Geological Society, London, p. 297-313.

Lu, J.C., Kobayashi, Y., Yuan, C.X., Ji, S.A., and Ji, Q., 2005, SEM observation of the wing membrane of Beipiaopterus chenianus (Pterosauria): Acta Geologica Sinica, v. 79, p. 766-769.

MARKwICK, P.J., 1998, Fossil crocodilians as indicators of Late Cretaceous and Cenozoic climates: Implications for using palaeontological data in reconstructing palaeoclimate: Palaeogeography, Palaeoclimatology, Palaeoecology, v. 137, p. 205-271.

Mazin, J.-M., Billon-Bruyat, J.P., HantzPergue, P., and Lafaurie, G., 2003, Ichnological evidence for quadrupedal locomotion in pterodactyloid pterosaurs: Trackways from the Late Jurassic of Crayssac (southwestern France), in Buffetaut
E., and Mazin, J.-M., eds., Evolution and Palaeobiology of Pterosaurs: Special Publications 217, Geological Society, London, p. 283-296.

Mazin, J.-M., Hantzpergue, P., Lafaurie, G., and Vignaud, P., 1995, Des pistes de pterosaures dans le Tithonien de Crayssac (Quercy, Lot): Comptes Rendus de l'Académie des Sciences, Paris, v. 321, 733-739.

Miall, A.D., 2006. The Geology of Fluvial Deposits: Springer, Berlin, 582 p.

Molnar, R.E., and Wiffen, J., 1994, A Late Cretaceous polar dinosaur fauna from New Zealand: Cretaceous Research, v. 15, p. 689-706.

Nelms, L.G., 1989, Late Cretaceous dinosaurs from the North Slope of Alaska [abs.]: Journal of Vertebrate Paleontology, v. 9, p. 34A.

Parrish, M.J., Parrish, J.T., Hutchinson, J.H., and Spicer, R.A., 1987, Late Cretaceous vertebrate fossils from the North Slope of Alaska and implications for dinosaur ecology: PALAIOS, v. 2, p. 377-389.

Rich, T.H., Vickers-Rich, P., and Gangloff, R.A., 2002, Polar dinosaurs: Science, v. 295 , p. $979-980$

Ridgway, K.D., Trop, J.M., and Sweet, A.R., 1997, Thrust-top basin formation along a suture zone, Cantwell basin, Alaska Range: Implications for the development of the Denali fault system: Geological Society of American Bulletin, v. 109 , p. $505-523$.

Rodriguez-De La Rosa, R.A., 2003, Pterosaur tracks from the latest Campanian Cerro del Pueblo Formation of southeastern Coahuila, Mexico, in Buffetaut, E. and Mazin, J.-M., eds., Evolution and Palaeobiology of Pterosaurs: Special Publications 217, Geological Society, London, p. 275-282.

Russell, D.A., 1993, The role of central Asia in dinosaurian biogeography: Canadian Journal of Earth Sciences, v. 30, p. 2002-2012.

SERENO, P.C., 2000, The fossil record, systematics and evolution of pachycephalosaurs and ceratopsians from Asia, in Benton, M.J., Shishkin, M.A., Unwin, D.M., and Kurochkin, E.N., eds., The Age of Dinosaurs in Russia and Mongolia: Cambridge University Press, Cambridge, U.K., p. 480-516.

Seymour, R.S., Bennett-Stamper, C.L., Johnston, S.D., Carrier, D.R., and GrigG, G.C., 2004, Evidence for endothermic ancestors of crocodiles at the stem of Archosaur evolution: Physiological and Biochemical Zoology, v. 77, p. 1051-1067. Unwin, D., 2006, The Pterosaurs: From Deep Time: Pi Press, New York. 347 p. Wellnhofer, P., 1991, The Illustrated Encyclopedia of Pterosaurs: Crescent Books, New York, 192 p.

Zhang, J., Li, D., Li, M., Lockley, M.G., and Bai, Z., 2006, Diverse dinosaur-, pterosaur-, and bird-track assemblages from the Hakou Formation, Lowe Cretaceous of Gansu Province, northwest China: Cretaceous Research, v. 27, p. 44-55.

ACCEPTED FEBRUARY 25, 2009 